RU Изучение современных китайско-русских контактных языков: некоторые особенности сино-русских идиолектов Приморского края

Гурьян Н. В.

\begin{abstract}
Аннотация. Цель исследования состоит в описании некоторых особенностей сино-русских идиолектов Приморского края в сопоставлении с другими хронологическими и региональными вариантами китайско-русских контактных языков. Научная новизна связана с анализом материала, который еще не становился предметом специального изучения в отечественной науке, а также с получением данных, позволяющих по-новому взглянуть на современные китайско-русские контактные идиомы. Полученные результаты показывают, что к сино-русским идиолектам плохо применим термин «пиджин» в силу их вариативности и особенностей социального функционирования. Анализ фонетикофонологического уровня сино-русских идиолектов позволил выявить черты, которые сближают их с другими хронологическими и региональными вариантами, а также некоторые совершенно новые характеристики (сохранение кластеров согласных), констатация которых идет вразрез с устоявшимися представлениями о фонетической структуре китайско-русских контактных языков.
\end{abstract}

\title{
EN Studying the Modern Sino-Russian Contact Languages: Some Features of the Sino-Russian Idiolects of Primorsky Krai
}

\section{Gurian N. V.}

\begin{abstract}
The purpose of the study is to describe some features of the Sino-Russian idiolects of Primorsky Krai as opposed to other chronological and regional variants of the Sino-Russian contact languages. Scientific novelty of the work lies in analysing the material that has never been a subject of a special study in the Russian science, as well as in collecting the data that make it possible to take a fresh look at the modern Sino-Russian contact idioms. The attained results show that the term "pidgin" is hardly applicable to the Sino-Russian idiolects due to their variation and peculiarities of social functioning. The analysis of the phonetic-phonological level of the Sino-Russian idiolects has allowed the researcher to identify the features that they share with other chronological and regional variants, as well as some entirely new characteristics (retention of consonant clusters), acknowledgement of which contradicts well-established views on the phonetic structure of the Sino-Russian contact languages.
\end{abstract}

\section{Введение}

В настоящее время контактная лингвистика - динамично развивающаяся область современной лингвистики. Языковые контакты становятся все более важной темой исследований, о чем свидетельствуют многочисленные зарубежные специальные и обобщающие работы. Так, только в 2020 вышли две коллективные англоязычные монографии [19; 20].

Как отмечает Э. Грант, в западной лингвистике языковые контакты различных языковых сообществ становятся основным направлением исследований со времен Второй мировой войны. Литература по этой теме огромна - написаны сотни книг и монографий, только на английском языке выходят два весьма уважаемых международных журнала: Journal of Pidgin and Creole Languages (с 1986 г. по настоящее время) и Journal of Language Contact (с 2007 г. по настоящее время) [17].

В современной креолистике при исследовании пиджинов наблюдается тенденция к обобщениям и поиску их общих структурных черт. Однако эти исследования по-прежнему сосредоточены в основном на пиджинах, возникших на базе западноевропейских языков: португальского, французского, английского. Трудно не согласиться с мнением, которое уже высказывалось отечественными лингвистами [8; 18], что точные кросслингвистические обобщения требуют учета языковых контактов, возникающих в разных языковых и социальных

Научная статья (original research article) | https://doi.org/10.30853/phil201019

(๔ 2021 Авторы. ООО Издательство «Грамота» (๔ 2021 The Authors. GRAMOTA Publishers). Открытый доступ предоставляется на условиях лицензии СС ВY 4.0 (open access article under the CС BY 4.0 license): https://creativecommons.org/licenses/by/4.0/ 
обстоятельствах. Таким образом, без введения в научный оборот данных по современным контактным языкам, возникшим при участии русского, эти обобщения будут далеко не полными.

Настоящее исследование призвано некоторым образом восполнить существующий пробел, поскольку направлено на документирование и описание современного контактного языка, образовавшегося в результате интенсивного русско-китайского взаимодействия на территории Приморского края РФ. Введение в научный оборот новейших материалов по языковым явлениям, возникающим при взаимодействии столь отличных по структуре языков, как русский и китайский, позволит как минимум расширить имеющиеся представления о последствиях языковых контактов в целом и контактов русско-китайских в частности, что и определяет актуальность настоящего исследования.

Исследование проводится в русле теории контактной лингвистики, а также относительно новой области, тесно связанной с полевой лингвистикой, - документирование языков. Языковая документация приобретает особую актуальность в последние годы. Эта область лингвистики направлена на сбор и накопление первичных данных о малоизученных языках и понимается как «долговременная многоцелевая фиксация языковых данных» [1].

Реализация поставленной цели подразумевает выполнение в работе следующих задач: 1) осветив историю вопроса, вписать проект по изучению сино-русских идиолектов Приморского края в контекст существующих исследований по проблеме; 2) рассмотреть применимость термина «пиджин» к объекту исследования; 3) на основе новейшего материала, собранного в ходе полевого исследования, выявить и показать некоторые особенности фонетико-фонологического уровня сино-русских идиолектов, сопоставив их с описаниями других разновидностей китайско-русских контактных языков; 4) на конкретном материале продемонстрировать вариативность сино-русских идиолектов как их характерную черту.

Исследование основано на материалах, собранных (в том числе автором настоящей статьи) в ходе полевого исследования в 2016-2017 гг. и 2020 г. в Приморском крае РФ (большая часть аудиозаписей сделана в г. Уссурийске). Языковой материал, анализируемый в настоящей статье, представляет собой выборку из расшифрованных спонтанных нарративов одиннадцати человек. Информантами выступали китайские мигранты (носители северокитайских диалектов), которые на момент записи прожили в России от 5 до 20 лет (краткие сведения о них приведены ниже). Ни один из информантов не получал существенного формального образования на русском языке. Собранные тексты получены в ответ на просьбу рассказать о жизни и работе в России, о праздниках, обычаях и т.п. В 2020 году была также апробирована методика сбора нарративов на основе фильма Уоллеса Чейфа «Рассказы о грушах» (Pear Stories). Обработка аудиозаписей осуществлялась с использованием программы Praat. Транскрипции текстов, фрагменты которых в настоящей работе иллюстрируют языковые явления сино-русских идиолектов, выполнены автором статьи.

Кроме общенаучных, в ходе исследования использовались следующие основные методы: описательноаналитический, сравнительно-сопоставительный, метод сплошной выборки.

Теоретической базой послужили работы специалистов в области полевой лингвистики и документирования малоизученных языков: А. А. Кибрика [3], А. В. Архипова [1], 3. Фрайзингера [16], а также работы лингвистов, изучавших китайско-русское языковое взаимодействие: А. Г. Шпринцина [12], А. Ю. Мусорина [4], Ян Цзе [13], Е. В. Перехвальской [7-10], Е. А. Оглезневой [5; 6] и др.

Практическая значимость. Результаты и выводы исследования могут быть использованы в ходе дальнейшего изучения данного лингвистического феномена, для составления вузовских курсов и спецкурсов по языкознанию, креолистике.

\section{Старые и новые китайско-русские контактные языки}

Китайско-русские контактные языки, описанные в литературе, хронологически подразделяются на «старые» и современные. К старым относится кяхтинский язык (маймачинское наречие), сформировавшийся в XVIII в. в зоне русско-китайской приграничной торговли в г. Кяхта.

Другой региональной разновидностью «старого» языка являлся дальневосточный вариант, бытовавший с середины XIX в. по 1930-е гг. XX в. в Приморском крае. Этот язык вышел из употребления к 1960-м гг. [10]. Китаевед А. Г. Шпринцин называл его дальневосточным «русско-китайским диалектом» [12].

Отдельной разновидностью стоит считать харбинский русско-китайский пиджин, бытовавший в период с 1898 г. до конца 1950-х гг. в Харбине и вдоль Китайско-Восточной железной дороги (КВЖД). Этот пиджин служил языком общения проживавших там разных этнических групп (китайцев, маньчжуров, корейцев, русских, а также русскоговорящих поляков, евреев, украинцев, татар, грузин, армян, немцев, латвийцев, литовцев, чехов, югославов и других). В отличие от кяхтинской и дальневосточной разновидности, лексика харбинского пиджина имела смешанный состав, на который китайский и русский языки повлияли примерно в равной степени [14].

Новейшие образования начали возникать в конце 80-х - начале 90-х годов XX в. благодаря улучшению российско-китайских торгово-экономических отношений и открытию российских границ. Как отмечает Ян Цзе [13], в указанный период были образованы пункты пропуска российских и китайских граждан с целью организации торговли товарами повседневного спроса. Территориями, где была санкционирована такая торговля, стали три населенных пункта: поселок Забайкальск (Забайкальский край) - г. Маньчжурия (КНР, автономный район Внутренняя Монголия); г. Благовещенск (Амурская область) - г. Хэйхэ (КНР, пров. Хэйлунцзян); станция Гродеково (Приморский край) - поселок Суйфэньхэ (КНР, пров. Хэйлунцзян). 
Нормализация китайско-советских, а затем китайско-российских отношений привела также к тому, что начиная с 90-х гг. XX в. на территории Дальнего Востока происходило увеличение численности китайцев [6; 15].

К числу факторов, определяющих высокую долю китайского населения в миграционном процессе на Дальнем Востоке, специалисты относят географическую близость КНР к России; высокий уровень незанятого населения в приграничных районах Северо-Восточного Китая, в том числе провинции Хэйлунцзян; внешнеэкономическую стратегию Китая, направленную на поддержку экспорта рабочей силы; преобладание экономических мотивов в международных миграциях в приграничных регионах Дальнего Востока [6].

Результатом указанных миграционных процессов явилось возникновение трех современных региональных вариантов китайско-русского контактного языка, которые в отечественной научной литературе принято называть «русско-китайским пиджином».

\section{Изучение «русско-китайских пиджинов»}

Как справедливо замечает Е. В. Перехвальская, до 1970-х гг. ХХ в. изучение русских пиджинов сводилось к фиксированию их наиболее показательных черт: отсутствие флективной морфологии, некоторые особенности фонетики, совмещение форм личных и притяжательных местоимений, существование единой глагольной формы и др., при отсутствии систематического анализа грамматики. «Многие статьи лишь обозначали тему, что не уменьшает их значимости. Это был совершенно логичный этап в изучении пиджинов» [8].

За прошедшие два десятилетия появилась серия публикаций, посвященных русско-китайскому языковому взаимодействию: работы Е. В. Перехвальской [7-10], Ян Цзе [13], К. С. Федоровой [15], Е. А. Оглезневой [5; 6], Р. Шапиро [18], Н. А. Ждановой [2], И. Ф. Поповой и Таката Токио [11] и др.

Лучше других на сегодняшний день изучен кяхтинский язык (маймачинское наречие), сформировавшийся в XVIII в. в зоне русско-китайской приграничной торговли. Внешняя история кяхтинского языка и история его изучения рассматриваются в $[6-8 ; 10 ; 11 ; 18]$ и др.

Подробное исследование старого русского пиджина, распространённого в XVIII-XX веках на территориях, поэтапно присоединяемых к России, включая систематический анализ грамматики и лексики, предпринято, прежде всего, в работах Е. В. Перехвальской, которая для его описания ввела термин «сибирский пиджин» [8]. Е. В. Перехвальская пришла к заключению, что «сибирский пиджин возник не в ходе контактов русских с китайцами. В основе русских пиджинов, функционировавших в XIX веке, лежал особый “язык для инородцев”, употреблявшийся русскими купцами и первыми переселенцами при общении с коренным населением Урала, Сибири и Дальнего Востока. Это был “прото-пиджин”, который содержал в себе те черты, которые объединяют “старые” русские пиджины» [Там же].

Обстоятельно выполненное описание старого пиджина на английском языке принадлежит российскому китаеведу Р. Шапиро [18]. В указанной работе её автор на основе старых и архивных материалов, редко доступных западным лингвистам, подробно обсуждает влияние обоих языков (русского и китайского) на все уровни пиджина (фонология, морфология, синтаксис, словарь), отмечает присутствие тунгусских и монгольских черт по причине бытования пиджина вдоль берегов Амура. Статья содержит приложение с примерами из записей С. И. Черепанова (1853), архива А. Г. Шпринцина, книги В. К. Арсеньева «По Уссурийскому краю. Дерсу Узала» (1853) и др., с переводом на английский язык.

В 2017 г. из печати вышло издание трех словарей кяхтинского пиджина [11], которые прежде не привлекали внимания исследователей. В этих словарях русские слова даны в передаче китайскими иероглифами. По мнению авторов издания, письменные памятники, вошедшие в него, являются уникальным источником для изучения как исчезнувших, так и ныне существующих контактных языков. Помимо впервые публикуемых текстов словарей, издание содержит подробный очерк по истории возникновения и бытования кяхтинского пиджина в контексте истории торговых отношений России и Китая через Кяхту и Маймайчен, а также филологические заметки о некоторых его особенностях.

Некоторое внимание русско-китайскому языковому контактированию уделено в работах К. С. Федоровой, так, в [15] особенности грамматической системы русско-китайского пиджина анализируется как с привлечением старых записей (из литературных произведений, работ лингвистов-предшественников), так и отчасти собственных полевых материалов 2006-2008 гг.

Что касается исследований новейших вариантов китайско-русского контактного языка, на сегодняшний день описание этих языковых образований предпринималось на материале идиома, имеющего хождение в Благовещенске - Хэйхэ [5], а также на материале идиома, который бытует на территории Забайкалья [2; 13].

\section{Изучение сино-русских идиолектов (на материале идиолектов Приморского края): первые результаты исследования}

Что касается контактного языка, наблюдаемого в Приморском крае, то до недавнего времени он еще не становился предметом специального изучения.

В 2016 г. к изучению этого языкового образования приступила российско-американская группа исследователей под руководством Зигмунта Фрайзингера (Zygmunt Frajzyngier), профессора Колорадского университета в г. Боулдере (США), которому и принадлежит сама идея исследования. С российской стороны в состав группы вошли сотрудники Дальневосточного федерального университета: Н. В. Гурьян и С. Ю. Карпенко. 
В течение 2016-2017 гг. были собраны первые записи образцов, начата их обработка и анализ. В 2020 г. проект «Документирование сино-русских идиолектов» получил финансовую поддержку РФФИ.

В фокусе нашего исследования находятся языки, на которых говорят китайские мигранты, проживающие/работающие на территории Приморского края РФ. Эти языки мы называем «сино-русскими идиолектами».

Первые результаты исследования сино-русских идиолектов нашли отражение в [19]. В этой работе дается краткий общий обзор грамматических особенностей сино-русских идиолектов, там же показано, что в своем речепроизводстве носители сино-русских идиолектов руководствуются коммуникативной потребностью, поэтому стремятся создавать лексические элементы в форме, понятной их русским слушателям. «Совершенно неожиданно оказывается, что место артикуляции сегментов, составляющих слово, является достаточным инструментом для достижения желаемого результата» [16, р. 692-693].

Кроме того, в рамках проекта по изучению и документированию сино-русских идиолектов предлагается рассматривать изучаемый язык не в качестве пиджина, а как совокупность идиолектов. Основанием тому служат особенности их социального функционирования, а также большая вариативность.

\section{Социальное функционирование сино-русских идиолектов}

Мы не располагаем доказательствами того, что язык, который в отечественной литературе принято называть «русско-китайским пиджином» (как старый «кяхтинский язык», так и новые образования, бытующие в Забайкалье и Благовещенске), когда-либо использовался в качестве языка общения между носителями китайского языка. Заметим, что Е. А. Оглезнева, изучавшая идиом, бытующий в Благовещенске - Хэйхэ, также подчеркивает, что носители русского языка стандартно общаются с китайцами на родном русском языке [5]. Таким образом, социальное функционирование сино-русских идиолектов отличается от функционирования пиджинов, включая пиджины на русской основе, по следующим критериям:

1) они не используются в мультиэтническом общении;

2) они не используются в общении между китайскими иммигрантами;

3) они не используются носителями русского языка, которые составляют большинство местного населения в данном регионе [16, р. 712].

\section{Вариативность сино-русских идиолектов}

Некоторые из записанных нами носителей сино-русских идиолектов прожили в России почти 20 лет, в то время как другие - всего 5 лет. Ни один из них не имел формального образования на русском языке. Эти носители используют сино-русские идиолекты только в общении с местным русским населением, но не в общении друг с другом или со своими детьми. По выражению 3. Фрайзингера (записано в частной беседе), в некотором смысле каждый носитель сино-русских идиолектов создает свой собственный идиолект из тех лексических элементов русского языка, которые были им услышаны и запомнены. В результате речь любого носителя сино-русских идиолектов отличается от речи других носителей.

Наши наблюдения над материалом свидетельствуют, что вариативность идиолектов довольно значительна и просматривается даже в рамках одного идиолекта. Покажем это далее при рассмотрении особенностей фонетико-фонологического уровня.

\section{Фонетико-фонологические особенности сино-русских идиолектов}

Как показывает анализ собранных данных, сино-русским идиолектам присущи как черты, которые роднят их с другими хронологическими и региональными вариантами китайско-русских контактных языков $[2 ; 5 ; 12 ; 18]$, так и те, что еще не описаны в литературе. Рассмотрим более подробно.

\section{1. Структура слога}

Считается, что «обычно, каждый говорящий на пиджине произносит слова в соответствии с нормами своего родного языка» [9, с. 150].

Как известно, структуры слогов в китайском и русском языках отличаются очень существенно. В китайском языке фонетический строй накладывает большие ограничения на сочетаемость звуков. Начальная позиция слога не допускает стечения согласных, в конце слога из согласных могут находиться только переднеязычный [-n] и велярный [-p]. В целом количество разных типов слогов сильно ограничено. В русском же языке слоговые структуры, напротив, весьма разнообразны. Различаются китайский и русский языки и характером ударения. Китайский относится к тоническим языкам, для русского языка характерно ударение динамическое (силовое).

А. Г. Шпринцин при описании фонетики дальневосточного «русско-китайского диалекта» выделил две стратегии, которые использовались китайцами при произнесении русских слов (примеры и транскрипция - А. Г. Шпринцина): 1) выпадение - отпадение согласного при их стечении в слоге (чела - вчера, суши слушать, капуса - капуста); 2) вставка гласного в группу согласных и приставка гласного в конце слога (часа час, дому - дом, соли - соль, собукэ - сопка). Оба фонетических процесса могут проявляться одновременно, особенно в многосложных словах (лабули - грабли) [12, с. 92]. 
Аналогичные процессы мы наблюдаем и на нашем материале. Выпадение/отпадение согласного: $v \supset k^{(h /} / v \jmath k^{h}$ «волк»; sna «знал/знает»; 'prəsə «просто»; si'vsn'a «сегодня»; 'd'ezə «здесь»; 'prav'inə «правильно», 'tluu «друг»;

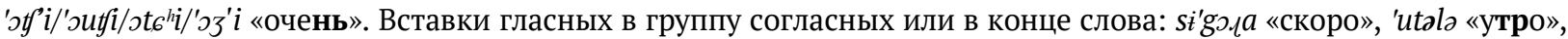
n'il'i'z'a «нельзя», 'lazinə «разные», 'ftfasi «сейчас», pa'tarakə «подарок»; 'ksta/'gədə «год»; 'tamu/'ta'me «там»; 'kakə kava'l'i «как сказать», dəlu'z'ja «друзья». Реализация одновременно двух стратегий: pu'rosi «просто». Интересно, что для слова «просто» зафиксирована и форма 'prssətadə, в которой сохраняется стечение согласных [pr-] в начале слова, но при этом срединный кластер [-st-] разбивается эпентетической вставкой.

Однако, судя по нашему материалу, указанные выше фонетические процессы находят отражение лишь в некоторой части слов. При этом зафиксированы многочисленные и разнообразные кластеры согласных в начальной и срединной позиции слова. Более того, в речи одного и того же информанта в рамках одного нарратива могут встречаться варианты как с сохранением кластеров согласных, так и с эпентезами, например: dolu'z'ja/d $u^{\prime} z$ 'ja «друзья». Ниже представим выборку из разных сино-русских идиолектов, демонстрирующую сохранение кластеров согласных (китайские информанты записаны под русскими именами, которыми они обычно представляются; из этических соображений имена информантов были изменены).

Юля (50 лет, из Дуннина, на момент записи проживала в РФ 12 лет): pasva'n'in'u «позвонит», 'tizdi(j)

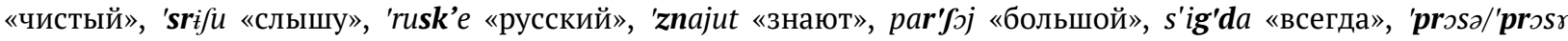
«просто», tvi'nats «двенадцать», s(i)'ksl'ks, 'mnэуa/'mnэgə «много», 'klufa «груша», 'p.lavda «правда», n’im'nsga

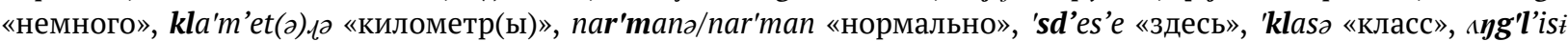
«английский», ka'n'efnə/ka'n'ezn «конечно», 'lantfə «раньше», vnuk «внук», 'mal'ing «ј «маленький», pal'faj «большой», 'sbtən «оптом», 'prosətadə «просто».

Борис (32 года, из Дуннина, на момент записи проживал в РФ 8 лет): 'nrazəət «нравится», razga'var'ut «разговариваю(-т?)», gub'l'u «куплю», tar'guj «торговать», ig'rat6 ${ }^{h}$ «играть», 'drasv'id'e «здравствуйте», u тn'i «мне», 'tritsə dva «тридцать два», 'vәs'mə «восемь», 'rusk'i «русский», k'i'desk'ij «китайский», 'krutikə «грузчик», dru'zja «друзья», 'vm'ess'e «вместе», 'smstr'i «смотрим», nar'mana «нормально», 'jesr'i «если», s'trjjka «стройка», 'xr'eba «хлеб», karba'saa «колбаса», 'mnoga «много», 'zd'es'i «здесь», 'sg ri «скоро», 'prazn'ige/'pranig'e «праздник», 'izza «из-за».

Иван (35 лет, из Суйфэньхэ, на момент записи имел десятилетний опыт общения с русскими):

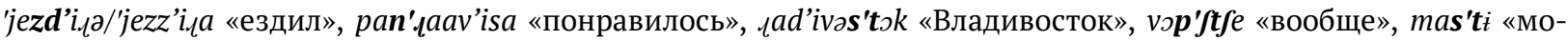

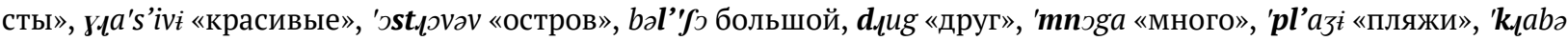
«краб», $f s^{\prime} \jmath$ «все».

Лида (38 лет, из Харбина, на момент записи проживала в РФ около 10 лет): zпаји «знаю», l'ub'l'u «люблю», 'd'in'g'i «деньги», kləda'ju 'plsхa «продаю плохо», fts «что?», 'tv'esid'i «двести», 'kl'ifk'i «крышки», st? «сто», lu'bləj «рублей», s'ig'da «всегда», k'i'tajsk'i «китайский», is'l'eej «если», tvats «двадцать», 'znaju «знаю», v usu'l'isk'ii «в Уссурийске», ja'bsysk'eе «японский», 'tluu «друг», pat'luga «подруга», 'tsblə «добрый», 'тэfna «можно», 'plsxa «плохо», ad'i'nakvi «одинаковый», 'slifftf «слышу».

Света (47 лет, из Харбина, на момент записи проживала в РФ более 10 лет): atkru'z'it'i «отгрузить», pr'ív'iklut'e «привыкли», smə'tr'i/sma'tr'i «смотри», ska'zat' «сказать», l'ub'l'u «люблю», tapaf'l'ats ${ }^{h}$ «добавлять», ras'tutsə «растут», n'e 'xvat'itsə «не хватит»; uf'la «ушла», 'svat'e «звать», pr'etpri'zзat'i «предупреждать», stu'tfat'i/stu'tfat'e «стучать», atk'riffiladk'ris'e «открыть», at'krj «открой», atk'ritaje «открытый», sna «знает», slu'fasə «случилось», n'e 'pэmn'u «не помню», fs'ว «все», s 'rusk'im «с русским», truk 'truku «друг другу», intə'rəjs «Интернет», 't'en'g'i «деньги», n’im'nəfka «немножко», tva «два», 'krupa/'kruba «группа», tv'i'nasi «двенадцать», s'i'vstn'a «сегодня», 'prasn'ikə «праздник», 'rasnəj «разные», 'pl'uta «блюда», fts «что», 'skrəmпәə «скромные», pra'tuk'ti «продукты», uta'pr'en'i «удобрение», xi'm'is’isk «химические», 'ploxa «плохо», 'vm'es'«вместе», 'papfka «бабушка», tva'i «твоя», kəg'd $a$ «когда», 'mal'in'kəja «маленькая», vav'ftfe «вообще».

Аноним (возраст и место проживания в Китае неизвестны): las'l'i «росли», b.' 'i'hod'etə «приходит»,

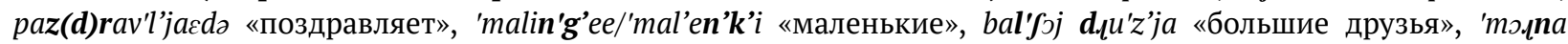

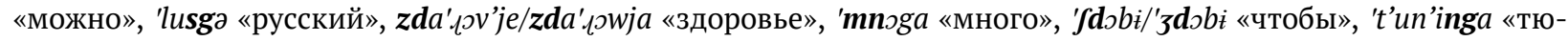

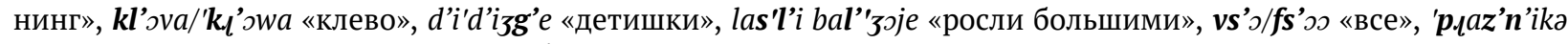
«праздник», 'bt'idza «птица», 'kurat'gah «курочка», pr'i'v'ed «привет».

Нина (49 лет, из Дуннина, на момент записи проживала в РФ 18 лет): 'nraitsa «нравится», pr'i'vikal’i «привыкли», n’i 'znaju / n’i 'znaj «не знаю», ska'za «сказала», ntjo «ничего/сносно», sva'ja «свой/свои», pastz'j'ana kl'i'jenta «постоянные клиенты», 'bavfkam'i «бабушки», 'mnsga «много», nar'mana «нормально», sam 'glana «самое главное», 'vəzdu(x) «воздух», 'skska «сколько», 'dılga «долго», da 'starən «до старости».

Люда (44 года, из Суйфэньхэ, на момент записи проживала в РФ 20 лет): tarkz'vatsa «торговать»,

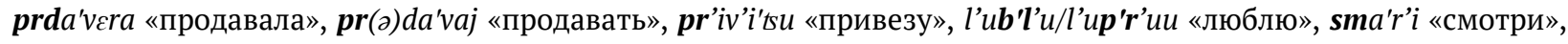
u mn'e «меня», t’iv'i'nəsta «девяносто», tvats «двадцать», 'rusk «русский», 'prəxə «плохо», 'tэgəə «только», 'lusk'ej tel'v'eka «русский человек», fs'ig'da «всегда», usu'^’iska «Уссурийск», nat'naj «ночной», 'lan'fə «раньше», para't'intse «полотенце», fs'ว «все», 'sptsm «оптом», ter'v'eka «человек», sdo'rsvije «здоровые», pa'tft'i «почти».

Андрей (45 лет, в РФ проживает 3,5 года, до приезда в РФ общался с русскими в г. Суйфэньхэ):

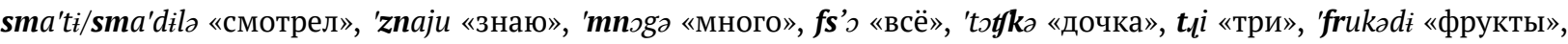
'klu'fe «груши», pa'dark «подарок», pl'i'lsta «природа», 'man'tk

Константин (42 года, из Харбина, в России в общей сложности с перерывами проживает около 5 лет, сообщил о желании лучше говорить по-русски): uk'lala/uk'rala «украл», nas'vəts/nnnaz'vətsə/naz'vajts «называется», stl'e'ffar/stl'e'tfala «встречал», zb'i'zala «сбежал», v'i.l'nutv «вернуться», vazrə'ftaits «возвращаться», 'sprafuje

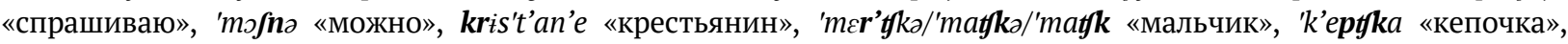




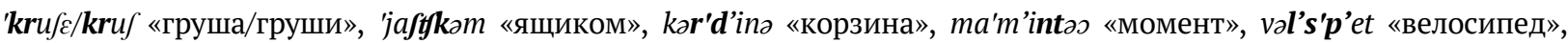
'pэslə «после», na'v'ernə «наверное», vaz'məfnə «возможно», tr'i/tl'i «три», dru'druka «друг друга», 'sksgə ftuk «сколько штук», 'kaldəv laz'd'il'il'is' «каждому разделил», pə'rusk'i «по-русски», kts «кто», kag'da/kag'ta «когда».

лёня (45 лет, из провинции Чжэцзян, на момент записи проживал в РФ 15 лет): zab'ract/zaba'l'aj/

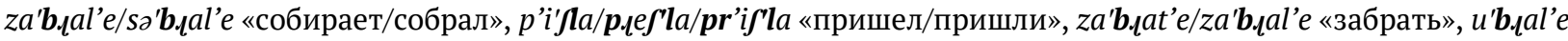
«убрал», 'stala «стало», 'gruљљ «груша», 'тєtk'i «мальчик», 't’iufka «девушка», sma'tela «смотрел», 'kamn'e «ка-

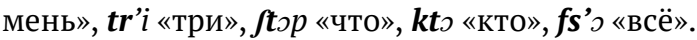

Кластеры согласных в конечной позиции слова на данный момент зарегистрированы единично: jesl' «если» (Света), 'gэrt «город» (Борис), ka'n'ezn «конечно» (Юля), 'таt k «мальчик» (Константин, Лёня).

Как видно из приведенных иллюстраций, в сино-русских идиолектах наблюдаются слоги самой разной структуры, что не вполне согласуется с теми выводами и обобщениями, которые были получены разными исследователями на материале других хронологических и региональных вариантов китайско-русских контактных языков $[2 ; 4 ; 6 ; 12 ; 18]$. Согласно этим выводам, «русско-китайский пиджин» не допускает сочетания согласных, а фонетическая структура слов соответствует закону открытого слога, поскольку «фонетические особенности пиджина - они, как и грамматические, во многом обусловлены стандартом родного языка, в данном случае - китайского» [2, с. 63]. Значительное количество лексических единиц в сино-русских идиолектах демонстрирует нарушение действия закона открытого слога.

Более того, в наших материалах встречается ряд слов, в которых происходит выпадение гласных по сравнению с исходными русскими формами, приводящее к стечению согласных, что абсолютно расходится с сегментной структурой китайского языка. В качестве примера приведем следующие: ad'i'nakvi «одинаковый», pr'etpri'zзat'i «предупреждать», prda'vera «продавала», 'k'eptka «кепочка», nas'vəts/nnnaz'vətsə/naz'vajts «называется», u mn'a / и mn'e «у меня»; padəmf'da/pa'dəmz'da/panəmf'da «потому что», ntfo «ничего/сносно», 'gərt «город», 'vэs'mə «восемь», vха'nəj «выходной», tel'v'iga «человек», kav'ritshi «говорить», 'bavfkam'i/'pap/ka «бабушки», 'jaft'kəm «ящиком», vəl's'p'et «велосипед».

Как было упомянуто выше, китайский язык не допускает согласных в конце слога, за исключением [-n] и [-p], в сино-русских идиолектах мы регистрируем немало слов, оканчивающихся на согласный (без вставки какого-либо эпентетического гласного $a / \partial / \dot{t} / u): d_{\iota} u g$ «друг»; pr'i'v'ed «привет»; ka'n'ezn «конечно»; naz'vajts «называется»; ftэp «что»; ftuk «штук»; 'stin'/'stim/'эзіmn «очень»; sin «сын»; vnuk «внук»; 'хиd'if «ходишь»; kruf «груша/груши»; 'znajut «знают»; la'pstət' «работать»; zit' «жить»; jes' «есть»; 'bud'it «будет»; 'n'et «нет»; ra'bət' «рабочие»; kab'i'dan «капитан, начальник»; mala't'es «молодец»; gət «год»; na 's'ever «на севере»; plox «плох(-ой)»;

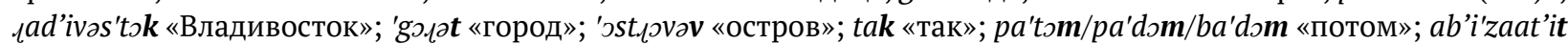

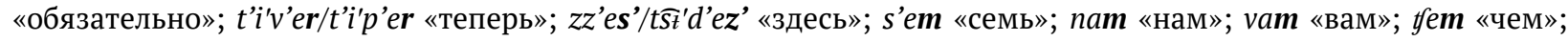
truk 'truku «друг другу»; kak ska'zat' / kak sə'zat' «как сказать»; fu-'tfud' «чуть-чуть»; kak 'ras «как раз»; sam 'glana «самое главное»; da 'starən «до старости», 'nrazəət «нравится», ig'rat ${ }^{h}$ «играть», 't'elat' «делать», 'snais «знает», u'p'is' «убить», a'd'i raz «один раз» и др.

\section{2. Ударение/тон}

Относительно словесного ударения в китайско-русских контактных языках в литературе высказывалось мнение, что каждое слово тонируется по типу китайских слов. Так, Н. А. Жданова со ссылкой на Е. В. Перехвальскую пишет: «...носители китайского языка имеют тенденцию “тонировать” слова как русского языка, так и русско-китайского пиджина, т.е. произносить их так, как если бы каждый слог был ударным. При этом каждый слог получает определенный тональный рисунок, что свойственно китайскому языку» [Там же]. Е. А. Оглезнева полагает, что в словах русско-китайского пиджина (имея в виду тот идиом, который распространен в Благовещенске - Хэйхэ) ударение соответствует китайскому стандарту [5].

Отечественные китаеведы, которые занимались изучением старых китайско-русских контактных языков, А. Г. Шпринцин [12] и Р. Шапиро [18], высказывались скептически относительно того, что слова «русскокитайского пиджина» могут быть тонированы. Более подробные рассуждения на этот счет см. [Ibidem, p. 13].

Наши собственные данные по сино-русским идиолектам не подтверждают факт ударности каждого слога в словах, по крайней мере, на системной основе. Хотя встречаются единичные примеры, которые выбиваются из общей картины, например: 'ta'me «там», 'vst'ka «водка». Кроме того, некоторые ударные слоги в отдельных словах производят впечатление китайского третьего тона, например: pasrav'l'aat'e «поздравлять», ab'i'zaat'it «обязательно»; pr'i'jaasn «приятно», 'maatk материалах у одного из информантов спорадически улавливается акцентная схема, свойственная китайским трехсложным словам (первый и последний слоги акцентированы, срединный слог слабоударный). Но этот вопрос требует отдельного изучения, что выходит за рамки настоящей статьи.

Всё же следует констатировать, что в подавляющем большинстве лексических единиц сино-русских идиолектов место ударения сохраняется аналогично русским этимонам даже в том случае, если звуковой состав слова подвергся редукции или изменилась его структура: 'drasv'id'e «здравствуйте»; 'хəd'ifi «ходишь»; на't'ila «ходила»; kar'i'fa «корефан»; sma'ti/sma'dilə «смотрел» и т.д. В редких случаях мы фиксируем два ударения, например 'wss'im'nats «восемнадцать»; pra'tuk'ti «продукты».

\section{3. Некоторые особенности артикуляции, мены звуков}

Традиционно отмечаемая для старых и современных китайско-русских контактных языков субституция [r]/[l] в сино-русских идиолектах реализуется в двух вариантах: [r] $\rightarrow[1],[1] \rightarrow[\mathrm{r} / \mathrm{d}]$, например pa sto lu'blaj «по сто рублей»; 'kakə kava'l'i «как говорить»; 'kl'ifk'i «крышки»; karba'saa «колбаса»; pa r'u'bə 'prazn'igə «по любому празднику»; na 'pэе 'jed'izə «на поле езжу» и т.д. 
Следует отметить, что субституция $[\mathrm{r}] \rightarrow[1]$ происходит далеко не всегда, $[\mathrm{r}]$ часто сохраняется или же заменяется китайским ретрофлексным [.]]: p.lef'la/pr'if'la «пришел/пришли»; dıu'z'ja «друзья»; truk 'truku «друг другу»; 'pıаz'n’ikə/'prasn'ikə/'pranə/'pranig'e/'prazn'ige «праздник» и т.д.

Вариативность идиолектов здесь проявляется в том, что одни и те же лексические единицы встречаются

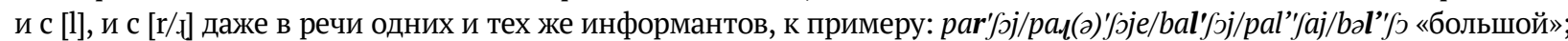
'rusk'ije/'rusk'i/'„uzg'i/'lusga/'rusk'e/'lusig'e/'luskə/'lusigəj/'lusigəjwe «русские/русский»; usu'r'i/usu','isika/usu'l'isk'ee/ usu'l'isk'ii/usu',lisk'e «Уссурийск»; 'kl’’va/'kı'эwa «клево»; dəlu'z'ja/dıl'z'ja «друзья» и т.д. Последние две пары вариантов для слов «клево» и «друзья» зарегистрированы у одного и того же информанта.

Русская аффриката [t6] (в наших транскрипциях используется символ $[\mathrm{t}]$ ), а также мягкий переднеязычный [ti] могут заменяться китайской ретрофлексной аффрикатой [t6 $\left.{ }^{\mathrm{h}}\right]:$ 'st'i/'sutfi/'stfin'/stchi/'sz'i/'stfim/'szimn

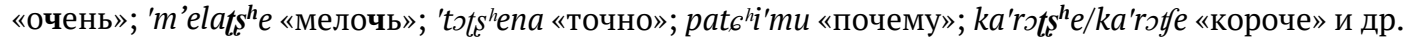

Хотелось бы привести некоторые субституции, которые пока трудно назвать системными, но тем не менее они фиксируются в отдельных идиолектах.

[n]/[l]: fa'lkrs/fals'r'ej «фонарей» («(праздник) фонарей»); la'rsta «народа»; lalə'тап^ «нормально», kl'i'mu «к нему», 'man'tka «мальчик(и)».

$[\mathrm{t}] /[\mathrm{t} \mathrm{j}] \rightarrow[\mathrm{s}] /\left[\mathrm{s}^{\mathrm{j}}\right]:$ 'snais «знает», u'p'is' «убить», adk'ris'e «открыть».

[dj]/[z]]: l'u'z'e/l'u'z'ej «людей», zz'es'/'zz'es'i «здесь», kәr'd'inə «корзина».

Для сино-русских идиолектов Приморского края не характерны мены [S] $\rightarrow[\mathrm{s}]$, а также [z] (3) $\rightarrow[\mathrm{z}]$, которые называет Е. А. Оглезнева [6]. Судя по нашим данным, [f] и [z] регулярно сохраняются: haa'f/нara'f/xar'fo

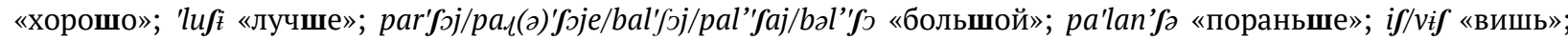

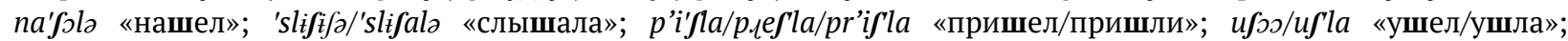

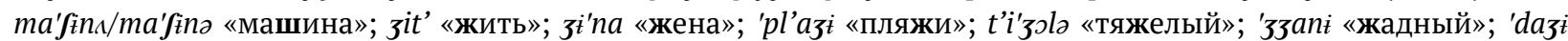

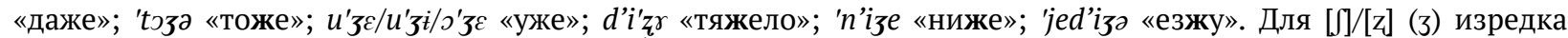

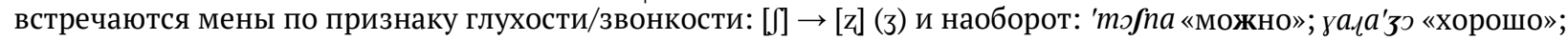
'tэfi «тоже»; $u^{\prime} \varepsilon \varepsilon$ «уже».

Таким образом, наряду с эпентетическими вставками гласных (т.н. «тенденцией избавления от закрытых слогов») или редукцией звуков и слогов, приводящей к упрощению кластеров согласных и сокращению количества слогов, а также субституции $[\mathrm{r}] \rightarrow[1]$, сино-русские идиолекты Приморского края демонстрируют некоторые фонетико-фонологические явления, которые отличают их от описанных в литературе старых и новых вариантов китайско-русских контактных языков.

\section{Заключение}

Выводы следует сформулировать следующим образом. Термин «пиджин» плохо применим к тому языку, который мы изучаем, по двум основаниям: 1) его социальное функционирование характеризуется однонаправленностью и тем самым отличается от функционирования пиджинов; 2) сино-русские идиолекты характеризуются высокой степенью вариативности. Таким образом, целесообразно рассматривать изучаемый язык как совокупность сино-русских идиолектов.

Фонетико-фонологические особенности сино-русских идиолектов демонстрируют, что языку, который мы изучаем, свойственны черты, присущие всем вариантам китайско-русских контактных языков (перестройка структуры слога и слова за счет эпентез или редукции, некоторые мены звуков), в то же время обнаруживаются и совершенно новые черты, а именно: многочисленные и разнообразные кластеры согласных в начальной и срединной позиции слова, что идет вразрез с устоявшимися представлениями о фонетической структуре китайско-русских контактных языков.

Документирование сино-русских идиолектов еще не завершено, оно продолжается в рамках действующего проекта РФФИ. В перспективе планируется выполнить описание грамматик всех собранных идиолектов, а также составить их словари. Кроме того, несмотря на отмеченную большую вариативность сино-русских идиолектов, они имеют некоторые общие черты. Необходимость установления этих общих черт и объяснения их природы определяет перспективы дальнейшего исследования.

\section{Финансирование}

Публикация подготовлена в рамках поддержанного РФФИ проекта № 20-012-00264, проект «Документирование сино-русских идиолектов».

\section{Список источников}

1. Архипов А. В. Документирование малых языков: научные и технические аспекты [Электронный ресурс]. URL: http://www.philology.ru/linguistics1/arkhipov-08.htm (дата обращения: 15.04.2020).

2. Жданова Н. А. Современный русско-китайский пиджин Забайкалья в структурно-системном и коммуникативном аспектах: дисс. ... к. филол. н. Улан-Удэ, 2016. 224 с. 
3. Кибрик А. Полевая лингвистика [Электронный ресурс]. URL: https://www.krugosvet.ru/enc/gumanitarnye_ nauki/lingvistika/POLEVAYA_LINGVISTIKA.html (дата обращения: 20.05.2019).

4. Мусорин А. Ю. Лексика кяхтинского пиджина [Электронный ресурс]. URL: http://www.philology.ru/linguistics4/ musorin-04a.htm (дата обращения: 15.08.2018).

5. Оглезнева Е. А. Русско-китайский пиджин на Дальнем Востоке: особенности функционирования и языковая специфика // Известия Российской академии наук. Серия литературы и языка. 2007. Т. 66. № 4. С. 35-52.

6. Оглезнева Е. А. Русско-китайское взаимодействие на дальневосточных территориях России: историколингвистический очерк // Слово: фольклорно-диалектологический альманах. 2010. № 8. С. 6-25.

7. Перехвальская Е. В. Русские пиджины. СПб.: Алетейя, 2008. 364 с.

8. Перехвальская Е. В. Сибирский пиджин (дальневосточный вариант). Формирование. История. Структура [Электронный ресурс]. URL: http://www.philology.ru/linguistics2/perekhvalskaya-06a.htm (дата обращения: 20.08.2020).

9. Перехвальская Е. В. Сибирский русский пиджин: вчера и сегодня // Вестник Российского гуманитарного научного фонда. 2008. № 4 (53). С. 147-164.

10. Перехвальская Е. В. Современные формы русского пиджина: уссурийский вариант [Электронный ресурс]. URL: http://www.helsinki.fi/slavicahelsingiensia/preview/sh40/pdf/11-sh40.pdf (дата обращения: 13.10.2020).

11. Словари кяхтинского пиджина / пер. с китайского, публикация, транскрипция, исследование и приложения И. Ф. Поповой и Таката Токио; Ин-т восточных рукописей (Азиатский музей) РАН. М.: Наука, 2017. 603 с.

12. Шпринцин А. Г. О русско-китайском диалекте на Дальнем Востоке // Страны и народы Востока. М.: Наука, 1968. Вып. VI. Страны и народы бассейна Тихого океана. С. 86-100.

13. Ян Цзе. Забайкальско-маньчжурский препиджин: опыт социологического исследования [Электронный pecypc]. URL: http://www.philology.ru/linguistics2/yan-tsze-07.htm (дата обращения: 07.10.2020).

14. Bakich O. Did You Speak Harbin Sino-Russian? [Электронный ресурc]. URL: https://www.cambridge.org/core/ journals/itinerario/article/abs/did-you-speak-harbin-sino-russian/FD3CA7391D83788802D688B515580831 (дата обращения: 01.11.2020).

15. Fedorova K. Language contacts on the Russian-Chinese border: the 'second birth' of Russian-Chinese trade pidgin // Perpetual motion? Transformation and transition in Central, Eastern Europe and Russia / ed. by T. Bhambry, C. Griffin, T. Hjelm, O. Voronina. L.: School of Slavonic and East European Studies, 2011. P. $72-84$.

16. Frajzyngier Z., Gurian N., Karpenko S. Language Contact: Sino-Russian // The Handbook of Language Contact. Second edition / ed. by R. Hickey. Hoboken, NJ: Wiley-Blackwell, 2020. P. 689-715.

17. Grant A. P. Contact-Induced Linguistic Change: An Introduction [Электронный ресурc]. URL: https://www.oxfor dhandbooks.com/view/10.1093/oxfordhb/9780199945092.001.0001/oxfordhb-9780199945092-е-1 (дата обращения: 09.11.2020).

18. Shapiro R. Chinese Pidgin Russian // Pidgins and Creoles in Asia. Amsterdam - Philadelphia: John Benjamins Publishing Company, 2012. P. 1-58.

19. The Handbook of Language Contact. Second edition / ed. by R. Hickey. Hoboken, NJ: Wiley-Blackwell, 2020.800 p.

20. The Oxford Handbook of Language Contact / ed. by A. P. Grant. Oxford: Oxford University Press, 2020. 792 p.

\section{Информация об авторах | Author information}

RU Гурьян Наталья Викторовна ${ }^{1}$, к. филол. н.

${ }^{1}$ Школа педагогики Дальневосточного федерального университета, г. Уссурийск

EN Gurian Natalia Viktorovna ${ }^{1}, \mathrm{PhD}$

${ }^{1}$ Far Eastern Federal University, School of Pedagogy, Ussuriysk

1 guryan-natalia@yandex.ru

\section{Информация о статье | About this article}

Дата поступления рукописи (received): 18.11.2020; опубликовано (published): 10.02.2021.

Ключевые слова (keywords): языковые контакты; языковая документация; китайско-русский контактный язык; русско-китайский пиджин; сино-русские идиолекты; language contacts; language documentation; SinoRussian contact language; Russian-Chinese pidgin; Sino-Russian idiolects. 